\title{
Animal Models in Allogenic Solid Organ Transplantation
}

\author{
Nadine Wenzel *, Rainer Blasczyk (D) and Constanca Figueiredo (D) \\ Institute of Transfusion Medicine and Transplant Engineering, Hannover Medical School, 30625 Hannover, \\ Germany; Blasczyk.Rainer@mh-hannover.de (R.B.); Figueiredo.Constanca@mh-hannover.de (C.F.) \\ * Correspondence: Wenzel.Nadine@mh-hannover.de
}

check for updates

Citation: Wenzel, N.; Blasczyk, R.; Figueiredo, C. Animal Models in Allogenic Solid Organ

Transplantation. Transplantology 2021,

2,412-424. https://doi.org/

10.3390/transplantology2040039

Academic Editor:

Wisit Cheungpasitporn

Received: 26 July 2021

Accepted: 24 September 2021

Published: 3 October 2021

Publisher's Note: MDPI stays neutral with regard to jurisdictional claims in published maps and institutional affiliations.

Copyright: (C) 2021 by the authors. Licensee MDPI, Basel, Switzerland. This article is an open access article distributed under the terms and conditions of the Creative Commons Attribution (CC BY) license (https:/ / creativecommons.org/licenses/by/ $4.0 /)$.

\begin{abstract}
Animal models provide the link between in vitro research and the first in-man application during clinical trials. They provide substantial information in preclinical studies for the assessment of new therapeutic interventions in advance of human clinical trials. However, each model has its advantages and limitations in the ability to imitate specific pathomechanisms. Therefore, the selection of an animal model for the evaluation of a specific research question or evaluation of a novel therapeutic strategy requires a precise analysis. Transplantation research is a discipline that largely benefits from the use of animal models with mouse and pig models being the most frequently used models in organ transplantation research. A suitable animal model should reflect best the situation in humans, and the researcher should be aware of the similarities as well as the limitations of the chosen model. Small animal models with rats and mice are contributing to the majority of animal experiments with the obvious advantages of these models being easy handling, low costs, and high reproductive rates. However, unfortunately, they often do not translate to clinical use. Large animal models, especially in transplantation medicine, are an important element for establishing preclinical models that do often translate to the clinic. Nevertheless, they can be costly, present increased regulatory requirements, and often are of high ethical concern. Therefore, it is crucial to select the right animal model from which extrapolations and valid conclusions can be obtained and translated into the human situation. This review provides an overview in the models frequently used in organ transplantation research.
\end{abstract}

Keywords: small animal model; large animal model; solid organ transplantation

\section{Introduction}

In many areas of biomedical research, the use of animal experiments is indispensable. As a result of this, the conducting scientist has a major responsibility toward science and animal welfare. Furthermore, one has to focus on the legal, ethical, and social impact [1].

For the transferability of research results from bench to bedside, in vivo studies are essential. In particular for the evaluation of mechanisms or responses depending on complex interactions within an organism, a living model is indispensable [2]. Although research on animal models has always been of ethical concern and needs to be well justified and planned according to Russel and Burch's 3R-Principle, it is important for the mimicking of a clinical situation and the translation into clinical practice. Transplantation medicine is one of the disciplines being fundamentally dependent on living systems.

New technologies and therapeutic strategies can only be proven safe and effective using specifically designed animal models [3]. Preclinical animal testing is still indispensable because it is providing valuable and fundamental understanding prior to early feasibility testing.

The transplantation of solid organs is a well-established medical intervention. Although technically challenging, it is considered a routine intervention for many organs; this holds especially true for the kidney [4].

The Global Observatory on Donation and Transplantation (GODT) is a cooperation project between the World Health Organization (WHO) and the National Transplant Or- 
ganization (Organización Nacional de Transplantes, ONT) of Spain. The purpose of the GODT is to collect data of allogenic transplantations. Data of 111 member states have been evaluated, representing $82.2 \%$ of the global population in the year 2015. A total number of 126,670 solid organ transplants were reported, consisting of 84,347 kidneys, 27,759 livers, 7023 heart transplantations, 5046 lung transplantations, 2299 pancreas, and 196 small bowel transplants [5]. For 2018 on the GODT website, a total number of 146,840 solid organ transplantations were reported, but this was still a number far less than the demand [6]. The discrepancy in this number is showing that there is still a tremendous need for research in this field. New approaches must be established to overcome the shortage of organs such as evaluation of marginal or organs of older donors to include them into the donor pool, improving organ protection strategies, and minimizing the ischemic and reperfusion damage or ex vivo machine perfusion for organ reconditioning [2,7].

Animal models are in need when in vitro or in silico systems cannot provide a reasonable and reproducible approach of an organism in vivo. The use of discarded human grafts to replace animal models is not feasible, as they are difficult to get and not available in a sufficient number to perform controlled studies [7].

In transplantation, the tight dependency between physiological functions, systemic interactions, and immune responses associated with the entire living system determine cell, tissue, or organ graft survival $[7,8]$. Therefore, animal models are essential to evaluate the therapeutic efficacy and safety of new approaches in the field of organ transplantation. However, finding the right animal model can be challenging: small animal models require specifically skilled personnel with specialized microsurgery abilities, which is often not available. In addition to the ethical concerns and regulatory burdens, large animal studies are extremely labor-intensive and expensive $[7,9]$.

To be able to get valid and reproducible data out of an experiment, the selection of an appropriate animal model is of utmost importance.

The understanding of the basic correlations of the immune response has been discovered in animal experiments. These experiments helped to provide a deep insight into the mechanisms of transplant immunology, rejection, and the modus operandi of immunosuppression as well as the opportunity to refine and develop surgical techniques [10].

Small and large animal models significantly contribute to the understanding of transplantation medicine. Here, as in other areas, the clinical relevance and potential for translation highly depends on appropriately designed experiments [11].

It will always be necessary to design and investigate new animal models to better represent the results of the latest research or better address unclear processes through in more optimized and standardized ways [8].

While designing a preclinical animal study, the researcher should provide a rationale for the choice of the animal model. It is of paramount importance that the animal model of choice reflects as close as possible the physiological attributes of the human situation. It is recommended to also address the limitations of that animal model by describing the deviations and the similarities between the selected model and the intention in humans [3].

The aim of this review is to give an overview of the most common animal models in allogeneic solid organ transplantation.

\section{Small Animal Models}

Small animal models with rats and mice are contributing to the majority of animal experiments. The obvious advantages of these models are well known, being easy handling, low costs, and high reproductive rates [12]. Rodents, rabbits, and guinea pigs are considered the main small animal species [13].

The first studies in small animal rodent models focused on transplant injury caused by ischemia/reperfusion injury (IRI) or immune-mediated rejection triggered by antibodymediated rejection (AMR). IRI causes the release of inflammatory mediators, inducing the activation of the innate immune response, resulting in sterile inflammation and microvascular alterations in transplanted organs [14]. Donor-specific antibodies may contribute to 
AMR by supporting microvascular changes, endothelial cell injury, increased intravascular macrophages, interstitial edema with or without hemorrhage, and neutrophilic infiltration $[15,16]$.

Rat models contributed significantly to clarify the immune response in vascularized and neovascularized setups. There are many genetically defined and well-characterized rat strains available for research purposes in transplantation immunology. In particular, the strains Brown-Norway (BN) and Lewis (LEW) are widely used [17].

Mice have always played an important role in a variety of disease models not only because of the extensive knowledge of their immune system and the possibility of genetical modification but also because of the immense availability of specific reagents. Mice as recipients and donors contributed significantly toward the understanding of the mechanisms of rejection and innate immune injury [10].

However, relevant differences exist between the immune system of humans and mice involving many signaling molecules and pathways, mediators, receptors, and the cell phenotype. Lymphocytes represent $30-50 \%$ of peripheral blood leukocytes in the human blood, whereas it is $75-90 \%$ in mice. The largest proportion of lymphocytes in the circulation are $T$ cells in humans and $B$ cells in mice $[11,18,19]$. The metabolism of immunosuppressive drugs is provided by Cytochrome P450 (CYP450). The CYP subfamily member CYP2J is coded by a single gene in humans but by four in rats and by eight genes in mice. This pharmacodynamic and pharmacokinetic differences are important to consider in the use of immunosuppressants [20,21]. In addition, it can be very challenging to obtain pure and reliable samples from small animals. Especially the collection of urine samples in a sufficient volume from rodents for standard urinary testing usually involves time-consuming procedures such as metabolic cages [22-24].

Although sharing many genetic homologies, the direct translation from mice to human has significant limitations. However, most of the proof-of-concept experimental setups do serve well as valuable proof of concept studies [25-28].

The insights gained with mouse models served as groundwork for studies in large animal models such as nonhuman primates [18].

Once the microsurgical techniques of transplantation were established in rodent models, a rapid increase in immunological basic knowledge arose. The advantage of mouse models is on the one hand the possibility of generating pathogen-free, genetically inbred stains which decrease the variability seen in many large animal models. The unique possibility of deleting and inserting specific genes by using genome-editing technologies such as CRISPR/Cas9, direct injection of DNA for the creation of transgenic mouse models, or for homologous recombination mediated by gene targeting to create knock-in and knockout models offered the opportunity to gain deeper insight into the complexity of the immune response. Mouse models of transplantation contributed tremendously to the identification of many relevant cytokines, chemokines, co-stimulatory ligands, and receptors [11,29].

However, the use of inbred strains also has the major drawback of a lack of genetic diversity, which does not resemble the situation in humans [30]. In addition, other contributing facts such as sex, obesity, age, various comorbidities, and organ-related issues such as ischemia times, which are the common variables in human transplantation, play a considerable role on the effects of the immune response and therefore on graft outcomes. If these facts could be integrated in a mouse transplantation model, it will significantly contribute to more translatability from mice to man [18].

The humanization of mice offers the chance for better translatability, and this powerful tool has evolved enormously since the first steps in 1988 [31].

Ajith et al. [32] recently reported the development of a personalized humanized mouse model for the evaluation of the alloimmune responsiveness between donor and recipient to minimize the immunological risk of allograft rejection in organ transplantation. In the future, this approach could also be used to evaluate the immune response in allogeneic cell-based therapies such as cell products derived from induced pluripotent or adult stem 
cells. This recipient's personalized humanized mouse model may contribute to the selection of the most histocompatible donor for a specific recipient with the lower number of HLA mismatches. As this model considers the varying immunogenicity of HLA antigens and the impact of non-HLA-related alloantigens, it may provide a strategy to maximize graft survival and reduce the dependency on immunosuppressive drugs.

As a result of the many species-specific differences between the mouse and the human immune system, the development of humanized mice led to the possibility to study the human immune response in a small animal model. This may become an important preclinical model to investigate the mechanisms of human allograft rejection. For instance, humanized mouse models have been used to investigate the mechanisms of islet allograft rejection, human T cell-mediated skin allografts, or xenograft rejection [33].

Rodent models of organ transplantation are suitable models to study the immunobiology of transplantation including acute, chronic, cellular, and humoral rejection and ischemia reperfusion injury, because of the wide availability of tools such as inbred, transgenic, and knockout animals; genetic mapping, monoclonal antibodies, and reagents $[34,35]$. This led to a continuous further development of the technique [36]. However, kidney transplantation in mice is known to be a challenging procedure with success rates ranging from 40 to $70 \%[37,38]$. Due to its complexity, it is only performed by a few experts [36].

Within the rodent models, rats do have advantages to mice as they are larger than mice, which makes surgical procedures less challenging in rats [12].

In order to achieve the desired and reproducible results in small animal solid organ transplantation models, there is the necessity of training. A certain number of operations and a timeframe of at least a couple of months or sometimes even years can be necessary, which might hinder the wider use of these techniques [39-45].

\subsection{Kidney Transplantation}

The rat kidney transplantation model is widely used for acute and chronic rejections as well as to study renal hypertension $[46,47]$. This experimental procedure has been standardized, and various new techniques contributed to the reduction of complications and therefore decreasing the number of animals needed [46-49]. Due to this, high long-term survival rates can be achieved with excellent vascular patency rates of up to $95 \%$ [50,51]. The orthotopic rat transplantation model is also a reproducible and reliable model to study different aspects of kidney transplantation such as acute, chronic, cellular, or antibodymediated rejection $[48,52]$.

Mouse models of vascularized kidney transplantation have been widely used to study the mechanism of IRI and transplant rejection. Removing the recipient's native kidneys $4-5$ days after transplantation decrease the probability of mortality during the early posttransplant phases due to delayed graft function. Nevertheless, the advantage of removing both native kidneys during the transplantation operation is that the immediate renal graft function can be monitored [14,53-55].

In brief, the donor's kidney is harvested for transplantation. For recipient procedures, transplant and bilateral native kidney removal is done either simultaneously $[56,57]$ or some days after transplantation [53,55]. The native kidney is removed first after opening of the abdomen; then, the donor kidney is transplanted.

However, graft loss can still be high due to arterial thrombosis because of turbulences in the blood flow leading to platelet activation and thrombus formation. A revised surgical technique using a cuff for a longer anastomosis and a straighter blood flow resulted in lessened thrombosis and therefore a better outcome. This surgical model provides a fully vascularized orthotopic kidney transplantation model, which can be used for graft tolerance and rejection studies, delayed graft function, and ischemia reperfusion injury studies [56,58].

Syngeneic and allogeneic mouse models have been used for testing IRI treatments in kidney transplantation models. However, the contribution of the individual mouse genetic background should be taken into account when planning and designing studies [14]. 
Despite the genetic disparities as mentioned above, and even considering that the rodent model is less expensive and better to manage, the direct translatability to human is limited also because of the anatomical differences between these two species. While humans and pigs have a multilobular and multipapillary kidney architecture, mice, rats, dogs and rabbits have unilobular, unipapillary kidneys [59].

\subsection{Liver Transplantation}

Animal models contributed significantly to the medical advances of liver transplantation. Although technically even more demanding, as the mouse liver vessels are eight times smaller than those of the average adult rat, a mouse orthotopic liver transplant model has been established. Mouse models are attractive because of their well-characterized genome and the possibility of knockout or transgenic models as well as the lower costs and the continuous availability of research substances [39].

In 1979, Naoshi Kamada pioneered in publicizing the first orthotopic rat liver transplantation using a cuff technique. This technique is well described and standardized and has been used worldwide since then $[42-45,60,61]$. During a 5-year period, Kamada performed more than 500 rat liver transplantations with a survival rate of $95.3 \%[42,43]$.

The cuff procedure shortens the anhepatic phase in the recipient animal, but it can be associated with foreign body reactions to the cuff [42].

Since then, alternative techniques such as cervical liver transplantation have emerged, but the Kamadas model remained the gold standard. For the rat, a literature review revealed 30 techniques or technical modifications [62].

The mouse model of orthotopic liver transplantation is especially attractive due to its similarity to man. Mice do have unlike rats a gallbladder, and they share a greater similarity between their histocompatibility complexes [39]. This model can give a comprehensive insight in research questions regarding immunobiology and pathobiology of the liver, tissue injury, regulation of alloimmunity, graft rejection, and tolerance induction, as well as liver biology and the pathogenesis of specific liver diseases.

In summary, the orthotopic liver transplantation in the mouse model is a useful tool in transplantation research and can contribute to new therapeutic interventions in this field.

\subsection{Heart Transplantation}

Heterotopic vascularized heart transplantation in a rodent model is a frequently used procedure to study the pathogenesis of graft rejection, immune response, the effects of IRI and graft preservation, as well as immunosuppressive regimes [63,64].

During this procedure, the heart of the donor animal is explanted and transplanted heterotopically into the abdomen of the recipient animal with the donor's ascending aorta anastomosed to the recipients infrarenal aorta, and the donor's pulmonary artery anastomosed to the recipient's inferior vena cava [41,65-67]. This recipient surgical procedure can also be performed using cervical vessels. In brief, the right cervical common carotid artery and external jugular vein of the recipient are isolated, and a Teflon cuff (Heron cuff technique) is placed over the caudal carotid artery and jugular vein. The donor aorta and pulmonary artery are connected to the cannula of the recipient cervical common carotid artery and external jugular vein and are ligated and fixed. If the transplanted heart is beating, the cervical incision can be closed [68,69].

It is a unique feature of this organ transplant model that graft monitoring can be done directly via palpation of pulsation in the abdomen without the need for repeated blood collection and blood chemistry [63].

This heart transplantation model is not life sustaining, and graft survival is not equated with animal survival. Acute rejection is defined by no palpable graft pulsation, and longterm survival is defined by viability of the graft beyond day 100 after transplantation. With chronic rejection, the heart rate decreases, the pulsation reduces linearly, and the heart size decreases. Animal death at or before day three is considered to be a technical failure [63]. Especially, the analysis of rejection processes in different mouse strains with defined genetic 
backgrounds offers the unique possibility to gain a deeper insight into immune interactions between receptors and ligands and their effect on physiological and pathophysiological mechanisms of acute and chronic graft rejection [67].

Heterotopic heart transplantation as an in vivo tool has been proven to be a solid vascularized immunological model in acute rejection or chronic transplant failure. As a result of the size, functional orthotopic heart transplantation cannot be performed in mice. In the heterotopic transplant, the ascending aorta is anastomosed to the abdominal aorta and the pulmonary artery is anastomosed to the vena cava. This is leading to a sufficient perfusion of the organ but only to a reduced workload of the graft [11].

Anatomical differences between man and mice regarding the vascular bed are limiting the use of this model for antibody-mediated rejection research. The human coronary arteries are supplied by vasa vasorum, the murine are not, and it is possible that these small vessels provide a route for inflammatory cells and cytokines into the coronary arteries of heart transplants in humans, but not in mice. Additionally, in the human heart, the coronaries are located on the surface, embedded in epicardial fat, and epicardial fat produces proinflammatory cytokines including IL-6, IL-8, and MCP 1 . In contrast to humans, in mice, only the first few millimeters of the coronary arteries are on the surface of the heart, and after that short distance, they pass through the myocardium $[67,70]$.

However, keeping these differences in mind, the in vivo model of heterotopic heart transplantation in rodents is a valuable tool with good experimental reproducibility.

\subsection{Lung Transplantation}

Although experiments on canine models laid the foundation for the first successful lung transplantation in humans, small animal models contributed significantly to gain further insight into the immune response to pulmonary grafts. However, eventually, the opportunity to successfully perform orthotopic vascularized lung transplantation in mice together with genetic tools paved the way to study in depth the immune and non-immune factors leading to lung graft rejection [71].

The rodent lung transplantation model is complex but meanwhile standardized and well replicable. This model gave insights into lung preservation models, ischemiareperfusion injury, and the mechanisms of acute and chronic rejection [72].

Lung transplantation is also described in a rat model, but the lack of specific antibodies compared to mouse models restricts the broader use of it. As already described for other organ transplantation models, the possibility of using a large variety of transgenic and knockout strains in mice and many available antibodies outweighs the seriously complicated surgery due to the size [73].

However, still, the rat model did its contributions, as the four phases of acute lung transplant rejection were defined in a rat lung transplantation model, indicating that bronchus-associated lymphoid tissue (BALT) within the lung graft played an important part in accelerating acute rejection [71]. BALT is expressed constitutively in rat lungs but not in mouse or human lungs where it can be induced after inflammatory processes. Due to the morphological differences in fibrotic airway obstruction in humans and rats, the orthotopic lung transplantation model in the rat is not broadly used.

\subsection{Large Animal Models}

Small animal models are the model of choice for proof of concept studies and protocol development but unfortunately often do not translate to clinical use. In addition, because rodent models highly depend on the surgeon's skills, therefore, they are not easy reproducible. Large animal models, especially in transplantation medicine, are an important element for establishing preclinical models, which often translate to the clinic [74].

For a long time, advances in transplantation have been based on the use of large animal models by bridging the gap between inbred mouse experimentation and the translation into human clinical trials [75]. 
Large animal models include sheep, goats, cows, pigs, horses, dogs, and primates. Among these, the most commonly used species are canines, swine, and nonhuman primates (NHPs) $[9,13]$. They all have similarities to human physiology and anatomy, which makes them suitable for preclinical studies. The dog model contributed significantly toward kidney transplantation, as the vessel anastomosis were established in this model [59].

However, the usage of pigs is driven by some beneficial facts: the pig is rated as a food source and therefore less ethical, and public resentments accompany the use of this species in research compared to dog or nonhuman primate models. As a result of their size, repeated sample taking is possible. In addition, pigs can be genetically modified, and the pigs genome has a high homology with humans [59]. Another advantage of the pig model is the similarly structured MHC Complex in comparison to humans. This is especially important in transplantation research [28,76]. Large animal models are of great interest in transplantation immunobiological research, as MHC class II expression levels and regulation of the endothelium is similar to humans. Therefore, dogs, pigs, and NHPs are frequently used in transplantation research, as their anatomy and immunobiology is close to that of humans [77].

The advantages of large animals compared to small animal models lays in the greater similarity of physiologically and anatomically characteristics such as size, tissue structure, and life expectancy. An important aspect is also that large animal species usually are outbred populations, which mimics more accurately the diversity of the human population.

Compared to small animal models, large animals provide a more clinically relevant model to test the translatability of new therapies [9,13].

A variety of large animal species have previously been used, but the necessity for highly specific and tailored therapies demands a model with a significant grade of homology to humans. As a consequence, nonhuman primates became the preferred choice in many experimental settings [75].

Although being the model that resembles the situation in humans at its best, the use of NHPs is often limited by increased regulatory requirements and ethical concerns. The high demands on husbandry and training, zoonotic risks, and the need for personal protective equipment are making these experiments extremely costly. Nevertheless, baboons, cynomolgus monkeys, and rhesus macaques do have the unique cross-reactivity with human immunoreagents. NHPs are frequently used in xenotransplantation research, using pigs as organ donors. Pigs are usually the donors, as they can be relatively easy genetically manipulated, e.g., with knockout of the Gal antigen. As a result of the size ratio, baboons are frequently used as recipients in solid organ pig xenotransplantation. Smaller NHPs, such as cynomolgus macaques, play an important role in xeno-islet transplantation [75].

In contrast, pig and dog models are a satisfactory solution offering a relative ease of experimental handling, lower costs of breeding and handling, and in terms of pigs, they are socially more accepted [9]. However, the choices of available species-specific immunoreagents are still limited, but the increased demand is leading to the development of new reagents [9].

\subsection{Kidney Transplantation}

Large animal models are crucial in renal transplantation research, as there are only a limited number of in vitro models available due to the complexity of this organ $[59,78,79]$.

As a result of the similar size of the kidney in swine and humans, the pig model is frequently chosen for research in the field of kidney transplantation and also for surgical training $[59,80]$.

In addition, pigs do have about $80 \%$ of immune parameters in common with humans, and they have about $50-70 \%$ of neutrophils in their peripheral blood; this is comparable to human rates. As in humans, pigs also express CXCL8/IL-8, their macrophages do not express iNOS but IFN- $\gamma$, and LPS do stimulate IDO (indoleamine 2,3 dioxygenase) in macrophages. The expression of CXCL-8/IL-8 correlates with disease severity in pigs and 
humans in acute kidney injury [81]. The main advantage of the pig model is the human-like renal anatomic structure with multipapillary and multilobular kidneys [59].

Swine and nonhuman primate models play an important role in pharmacological preclinical studies regarding safety and efficacy [59].

In contrast to the suitability of pigs as a preclinical model stand some impairments such as the fast growth rates, which puts high demands on the housing and some anatomic specialties.

Regarding the operation, pigs have some unique anatomic structures and characteristics that a surgeon has to keep in mind. Especially, the narrow ureter and its mucosa is prone to edema, making this part of the transplantation challenging. Complications during surgery could also result from malignant hyperthermia, cardiac irregularities, peptic ulceration, and post-operative small-bowel obstruction [82,83].

\subsection{Liver Transplantation}

Large animal models for liver transplantation are extremely difficult models, as the prepared situation of acute liver failure results in a high mortality rate. In large animal models, the pig is the dominant species in use [84-86]. Still, these animal models often do not lead to translation into clinically relevant settings. The nature of liver disease plays an important role in this part, as the damage usually accumulates over years with severe impairment of both liver structure and function. The injuries developed in animal models are usually milder and occur in a timeframe of days or weeks. When it comes to the recovery of liver injuries, a realistic preclinical animal model is still lacking [87].

\subsection{Heart Transplantation}

In cardiovascular research, it is obvious that data from small animal models with their high heart rates (300-840 beats per min in mice and $330-480$ beats per min in rats), small organ size, different metabolic rates, and action potential durations cannot easily translate to humans. As a result, many therapeutics, which seemed promising in the rodent model, failed in large animals and humans.

Large animal models such as pigs, dogs, and sheep are more suitable models in cardiovascular research, with pigs and sheep being mostly the model of choice. Pigs and sheep do resemble the human situation closely regarding heart size, immune system, and anatomy. However, one major disadvantage of the pig model is the susceptibility to tachyarrhythmias and sudden death [88].

However, the pig still remains the best choice over other animals such as sheep and dogs as a preclinical model of orthotopic heart transplantation [89].

The heart of the pig is anatomically similar to humans, which makes it particularly suitable for cardiac transplantation research. Still, the surgeon needs to pay attention to some drawbacks: the porcine heart and pulmonary artery is very delicate and prone to tears. Furthermore, as already stated, the pig's heart is very sensitive to arrhythmias, which makes it necessary to routinely administer anti-arrythmetic drugs prior to surgery.

An important anatomic difference between the porcine and the human heart is the existence of the left hemiazygous vein, which drains directly into the coronary sinus and has to be ligated during surgery. Although the porcine heart is very sensitive to ischemia, it is still an appropriate model for heart transplantation studies. This procedure requires a trained and experienced surgeon to be performed, but consistency and repetition makes it an optimized and reliable model $[89,90]$.

\subsection{Lung Transplantation}

As in kidney transplantation, pigs are also a suitable model for lung transplantation, as they have a comparable size of the organ compared to humans. This makes them the optimal model for research in ex vivo lung perfusion (EVLP). As a result of the similarities in size, tidal volumes, and positive end-expiratory pressure, the same equipment that 
would be used in humans can be used, which makes the findings directly transferrable to clinical trials [91].

Dog models were crucially important for the development of the surgical procedure to translate into the first human lung transplantation. Canines were thought to be suitable large animal models in transplantation research of solid organs and hemapoietic stem cells because they are an outbred species and therefore have a larger variety in MHC antigens. However, due to ethical considerations and their pet status, the canine model became irrelevant $[92,93]$.

As a result of the anatomical analogy, the surgical techniques from human lung transplantation can be transferred to the pig model. The one major difference is the right pig lung, which consists of four lobes and has a tracheal bronchus. As a result of this, transplantation of the left lung is the preferred.

However, a pig lung transplantation is a demanding procedure that requires a skilled surgeon and a minimum of ten procedures for a learning. However, once initialized, the mortality is around $0 \%$ for this established method $[92,94]$.

Table 1 summarizes the general pros and cons of small and large animal models.

Table 1. Pros and cons of small and large animal models.

\begin{tabular}{|c|c|c|c|}
\hline \multicolumn{2}{|c|}{$\begin{array}{c}\text { Small Animal Model } \\
\text { (Mouse, Rat, Guinea Pig, Rabbit) }\end{array}$} & \multicolumn{2}{|c|}{$\begin{array}{c}\text { Large Animal Model } \\
\text { (Pig, Sheep, Goat, Dogs, Nonhuman Primates) }\end{array}$} \\
\hline Pro & Con & Pro & Con \\
\hline $\begin{array}{l}\text { Large availability of } \\
\text { markers, antibodies, and } \\
\text { other reagents }\end{array}$ & $\begin{array}{l}\text { Limitations in sample } \\
\text { volume and number of } \\
\text { repeated sampling }\end{array}$ & $\begin{array}{l}\text { Larger volumes of samples and } \\
\text { higher frequency of sampling } \\
\text { possible, potentially increasing } \\
\text { statistical power }\end{array}$ & $\begin{array}{l}\text { Reduced availability of } \\
\text { reagents }\end{array}$ \\
\hline $\begin{array}{l}\text { Easy breeding, cheap, easy } \\
\text { handling }\end{array}$ & Short lifespan & Longer lifespan for chronic models & $\begin{array}{c}\text { Costly, long breeding } \\
\text { periods, difficult handling }\end{array}$ \\
\hline $\begin{array}{l}\text { Reduced costs for } \\
\text { pharmacological substances, } \\
\text { because of body weight }\end{array}$ & $\begin{array}{l}\text { Rapid disease induction in } \\
\text { surgical models vs. mostly } \\
\text { slow disease progression in } \\
\text { patients }\end{array}$ & Surgeries easier to perform & $\begin{array}{l}\text { Increased regulatory } \\
\text { requirements }\end{array}$ \\
\hline Sequenced genome & $\begin{array}{l}\text { Often inbred strains, do not } \\
\text { reflect the heterogeneity of } \\
\text { the patient population }\end{array}$ & $\begin{array}{l}\text { Mostly out bred population, better } \\
\text { representing the heterogeneity of } \\
\text { population, physiologically and } \\
\text { anatomically similar to human } \\
\text { (body size, tissue structure, and life } \\
\text { expectancy) and with greater } \\
\text { sequencehomology }\end{array}$ & High ethical concern \\
\hline
\end{tabular}

\section{Conclusions}

Although a large number of animal experiments are conducted worldwide, only about one-third is translated to human trials in the clinics [95].

Transplantation research represents an exception toward this tendency, as this discipline largely benefits from the use of animal models [96-98]. At present, mouse and pig models are the most frequently used models in organ transplantation research, and they replaced the earlier canine models [99].

While planning preclinical animal research projects, a sound rationale for the selection of the animal model in use should be provided. This animal model should reflect best the situation in humans, and the similarities as well as the limitations of the model should be described [3].

There is no perfect animal model that completely mimics the situation in humans or clinical trials. However, a continuous effort has to be made to collect as much translatable data as possible out of experimental animal models. This will contribute directly toward finding the appropriate model and therefore reducing animal numbers. 
Author Contributions: N.W. wrote the manuscript with support from R.B. and C.F. All authors reviewed and approved the final version of the manuscript.

Funding: This study was funded by the European Fonds for Regional Development and State of Lower Saxony ZW 6-85019222-Consortium Invisible Organs.

Institutional Review Board Statement: Not applicable.

Informed Consent Statement: Not applicable.

Data Availability Statement: Not applicable.

Conflicts of Interest: The authors declare no conflict of interests.

\section{References}

1. Geise, W. Guidelines for the Use and Care of Small Laboratory Animals in Transplantantation Research. In OrganTransplantation in Rats and Mice: Microsurgical Techniques and Immunological Principles; Timmermann, W., Gassel, H.-J., Ulrichs, K., Zhong, R., Thiede, A., Eds.; Springer: Berlin/Heidelberg, Germany, 1998; pp. 27-40.

2. Minor, T.; Schemmer, P. Organprotektion und OrganTransplantation. Allgemein-und Viszeralchirurgie Up2date $2009,3,131-146$. [CrossRef]

3. Park, S.E.; Schaer, T.P. Preclinical Animal Models. Acad. Entrep. Med. Health Sci. 2019, 1, 20.

4. Orlando, G.; Soker, S.; Stratta, R.J.; Atala, A. Will regenerative medicine replace Transplantation? Cold Spring Harb. Perspect. Med. 2013, 3, a015693. [CrossRef]

5. Mahillo, B.; Carmona, M.; Alvarez, M.; Marco, J.; Nuñez, J.R.; López-Fraga, M.; Matesanz, R.; Domínguez-Gil, B. Worldwide distribution of solid organ Transplantation and access of population to those practices. Transplantantation 2018, 102, S71-S72. [CrossRef]

6. Loupy, A.; Aubert, O.; Reese, P.P.; Bastien, O.; Bayer, F.; Jacquelinet, C. Organ procurement and Transplantation during the COVID-19 pandemic. Lancet 2020, 395, e95-e96. [CrossRef]

7. Cavalcante, L.D.S.; Toner, M.; Uygun, K.; Tessier, S.N. Leveraging the zebrafish to model organ Transplantation. Curr. Opin. Organ Transplant. 2019, 24, 613-619. [CrossRef]

8. Muschler, G.F.; Raut, V.P.; Patterson, T.E.; Wenke, J.C.; Hollinger, J.O. The Design and Use of Animal Models for Translational Research in Bone Tissue Engineering and Regenerative Medicine. Tissue Eng. Part B Rev. 2010, 16, 123-145. [CrossRef]

9. Matar, A.J.; Crepeau, R.L.; Duran-Struuck, R. Cellular Immunotherapies in Pre-Clinical Large Animal Models of Transplantantation. Biol. Blood Marrow Transplant. 2020, 27, 36-44.

10. Gunaratnam, L.; Jevnikar, A.M.; Mannon, R.B. Small Animal Models of Transplantantation. Textb. Organ Transplant. 2014, 158-184. [CrossRef]

11. Baldwin, W.M., III; Su, C.A.; Shroka, T.M.; Fairchild, R.L. Experimental models of cardiac Transplantation: Design determines relevance. Curr. Opin. Organ Transplant. 2014, 19, 525-530. [CrossRef]

12. Kim, Y.-Y.; Kim, J.-S.; Che, J.-H.; Ku, S.-Y.; Kang, B.-C.; Yun, J.-W. Comparison of Genetically Engineered Immunodeficient Animal Models for Nonclinical Testing of Stem Cell Therapies. Pharmaceutics 2021, 13, 130. [CrossRef]

13. Hotham, W.; Henson, F. The use of large animals to facilitate the process of MSC going from laboratory to patient-'bench to bedside'. Cell Biol. Toxicol. 2020, 1-12. [CrossRef]

14. Qiu, L.; Zhang, Z.J. Therapeutic Strategies of Kidney Transplantant Ischemia Reperfusion Injury: Insight From Mouse Models. Biomed. J. Sci. Tech. Res. 2019, 14, 002617.

15. Baldwin, W.M., III; Valujskikh, A.; Fairchild, R.L. Antibody-mediated rejection: Emergence of animal models to answer clinical questions. Am. J. Transplant. 2010, 10, 1135-1142. [CrossRef]

16. Jindra, P.T.; Hsueh, A.; Hong, L.; Gjertson, D.; Shen, X.-D.; Gao, F.; Dang, J.; Mischel, P.S.; Baldwin, W.M.; Fishbein, M.C.; et al. Anti-MHC Class I Antibody Activation of Proliferation and Survival Signaling in Murine Cardiac Allografts. J. Immunol. 2008, 180, 2214-2224. [CrossRef]

17. Zinöcker, S.; Dressel, R.; Wang, X.-N.; Dickinson, A.M.; Rolstad, B. Immune Reconstitution and Graft-Versus-Host Reactions in Rat Models of Allogeneic Hematopoietic Cell Transplantantation. Front. Immunol. 2012, 3, 355. [CrossRef]

18. Chong, A.S.; Alegre, M.-L.; Miller, M.L.; Fairchild, R.L. Lessons and Limits of Mouse Models. Cold Spring Harb. Perspect. Med. 2013, 3, a015495. [CrossRef]

19. Garraud, O.; Borhis, G.; Badr, G.; Degrelle, S.; Pozzetto, B.; Cognasse, F.; Richard, Y. Revisiting the B-cell compartment in mouse and humans: More than one B-cell subset exists in the marginal zone and beyond. BMC Immunol. 2012, 13, 63. [CrossRef]

20. McDaid, J.; Scott, C.J.; Kissenpfennig, A.; Chen, H.; Martins, P.N. The utility of animal models in developing immunosuppressive agents. Eur. J. Pharm. 2015, 759, 295-302. [CrossRef]

21. Costello, R.; Kissenpfennig, A.; Martins, P.N.; McDaid, J. Development of Transplant immunosuppressive agents-Considerations in the use of animal models. Expert Opin. Drug Discov. 2018, 13, 1041-1053. [CrossRef]

22. Demirkan, A.; Melli, M. A simple and inexpensive device for collecting urine samples from rats. Lab Anim. 2007, 36, 39-41. [CrossRef] 
23. Hoffman, J.F.; Fan, A.X.; Neuendorf, E.H.; Vergara, V.B.; Kalinich, J.F. Hydrophobic Sand Versus Metabolic Cages: A Comparison of Urine Collection Methods for Rats (Rattus norvegicus). J. Am. Assoc. Lab. Anim. Sci. 2018, 57, 51-57.

24. Kurien, B.T.; Scofield, R.H. Mouse urine collection using clear plastic wrap. Lab. Anim. 1999, 33, 83-86. [CrossRef]

25. Brown, S.; Hancock, J. The mouse genome. Vertebr. Genomes 2006, 2, 33-45.

26. Chinwalla, A.T.; Cook, L.L.; Delehaunty, K.D.; Fewell, G.A.; Fulton, L.A.; Fulton, R.S. Initial sequencing and comparative analysis of the mouse genome. Nature 2002, 420, 520-562.

27. Perlman, R.L. Mouse Models of Human Disease: An Evolutionary Perspective. Evol. Med. Public Health 2016, $2016,170-176$. [CrossRef]

28. Riehle, C.; Bauersachs, J. Small animal models of heart failure. Cardiovasc. Res. 2019, 115, 1838-1849. [CrossRef] [PubMed]

29. Miura, H.; Quadros, R.M.; Gurumurthy, C.B.; Ohtsuka, M. Easi-CRISPR for creating knock-in and conditional knockout mouse models using long ssDNA donors. Nat. Protoc. 2018, 13, 195-215. [CrossRef] [PubMed]

30. Reichenbach, D.K.; Li, Q.; Hoffman, R.A.; Williams, A.L.; Shlomchik, W.D.; Rothstein, D.M.; Demetris, A.J.; Lakkis, F.G. Allograft Outcomes in Outbred Mice. Arab. Archaeol. Epigr. 2013, 13, 580-588. [CrossRef] [PubMed]

31. Mosier, D.E. Immunodeficient mice xenografted with human lymphoid cells: New models forin vivo studies of human immunobiology and infectious diseases. J. Clin. Immunol. 1990, 10, 185-191. [CrossRef]

32. Ajith, A.; Mulloy, L.L.; Musa, A.; Bravo-Egana, V.; Horuzsko, D.D.; Gani, I.; Horuzsko, A. Humanized Mouse Model as a Novel Approach in the Assessment of Human Allogeneic Responses in Organ Transplantantation. Front. Immunol. 2021, 12. [CrossRef]

33. Kenney, L.L.; Shultz, L.D.; Greiner, D.L.; Brehm, M. Humanized Mouse Models for Transplantant Immunology. Am. J. Transplant. 2016, 16, 389-397. [CrossRef]

34. Martins, P.N. Technique of kidney Transplantation in mice with anti-reflux urinary reconstruction. Int. Braz. J. Urol. 2006, 32, 713-720. [CrossRef] [PubMed]

35. Tse, G.H.; Hughes, J.; Marson, L.P. Systematic review of mouse kidney Transplantation. Transplant. Int. 2013, 26, 1149-1160. [CrossRef] [PubMed]

36. Martins, P.N. Learning curve, surgical results and operative complications for kidney Transplantation in mice. Microsurgery 2006, 26, 590-593. [CrossRef] [PubMed]

37. Rong, S.; Lewis, A.G.; Kunter, U.; Haller, H.; Gueler, F. A Knotless Technique for Kidney Transplantantation in the Mouse. J. Transplant. 2012, 2012, 1-6. [CrossRef]

38. Wang, L.; Wei, J.; Jiang, S.; Li, H.-H.; Fu, L.; Zhang, J.; Liu, R. Effects of different storage solutions on renal ischemia tolerance after kidney Transplantation in mice. Am. J. Physiol. Physiol. 2018, 314, F381-F387. [CrossRef] [PubMed]

39. Li, T.; Hu, Z.; Wang, L.; Lv, G.-Y. Details determining the success in establishing a mouse orthotopic liver Transplantation model. World J. Gastroenterol. 2020, 26, 3889-3898. [CrossRef] [PubMed]

40. Yokota, S.; Yoshida, O.; Ono, Y.; Geller, D.A.; Thomson, A.W. Liver Transplantation in the mouse: Insights into liver immunobiology, tissue injury, and allograft tolerance. Liver Transplant. 2015, 22, 536-546. [CrossRef]

41. Westhofen, S.; Jelinek, M.; Dreher, L.; Biermann, D.; Martin, J.; Vitzhum, H.; Reichenspurner, H.; Ehmke, H.; Schwoerer, A.P. The heterotopic heart Transplantation in mice as a small animal model to study mechanical unloading-Establishment of the procedure, perioperative management and postoperative scoring. PLoS ONE 2019, 14, e0214513. [CrossRef]

42. Ishii, E.; Shimizu, A.; Takahashi, M.; Terasaki, M.; Kunugi, S.; Nagasaka, S.; Terasaki, Y.; Ohashi, R.; Masuda, Y.; Fukuda, Y. Surgical technique of orthotopic liver Transplantation in rats: The Kamada technique and a new splint technique for hepatic artery reconstruction. J. Nippon. Med. Sch. 2013, 80, 4-15. [CrossRef] [PubMed]

43. Kamada, N.; Calne, R.Y. A surgical experience with five hundred thirty liver Transplants in the rat. Surgery 1983, 93, 64-69.

44. Man, K.; Lo, C.-M.; Oi-Lin, I.; Wong, Y.-C.; Qin, L.-F.; Fan, S.-T.; Wong, J. Liver Transplantantation in Rats Using Small-for-Size Grafts: A Study of Hemodynamic and Morphological Changes. Arch. Surg. 2001, 136, 280-285. [CrossRef] [PubMed]

45. Oldani, G.; Maestri, M.; Gaspari, A.; Lillo, E.; Angelastri, G.; Lenti, L.M.; Rademacher, J.; Alessiani, M.; Dionigi, P. A Novel Technique for Rat Liver Transplantantation Using Quick Linker System: A Preliminary Result. J. Surg. Res. 2008, 149, 303-309. [CrossRef] [PubMed]

46. Martins, P.N.A. Kidney Transplantation in the rat: A modified technique using hydrodissection. Microsurgery 2006, 26, 543-546. [CrossRef] [PubMed]

47. Pahlavan, P.; Mehrabi, A.; Kashfi, A.; Soleimani, M.; Fani-Yazdi, S.; Schemmer, P.; Gutt, C.; Friess, H.; Weitz, J.; Kraus, T.; et al. Guidelines for Prevention and Management of Complications Following Kidney Transplantantation in Rats. Transplant. Proc. 2005, 37, 2333-2337. [CrossRef] [PubMed]

48. Karatzas, T.; Santiago, S.; Xanthos, T.; de Faria, W.; Gandia, C.; Kostakis, A. An easy and safe model of kidney Transplantation in rats. Microsurgery 2007, 27, 668-672. [CrossRef] [PubMed]

49. Pahlavan, P.S.; Smallegange, C.; Adams, M.A.; Schumacher, M. Kidney Transplantation procedures in rats: Assessments, complications, and management. Microsurgery 2006, 26, 404-411. [CrossRef]

50. Gu, Y.L.; Dahmen, U.; Dirsch, O.; Broelsch, C.E. Improved renal Transplantation in the rat with a nonsplinted ureteroureterostomy. Microsurgery 2002, 22, 204-210. [CrossRef]

51. Yuzefovych, Y.; Valdivia, E.; Rong, S.; Hack, F.; Rother, T.; Schmitz, J.; Bräsen, J.H.; Wedekind, D.; Moers, C.; Wenzel, N.; et al. Genetic Engineering of the Kidney to Permanently Silence MHC Transcripts During ex vivo Organ Perfusion. Front. Immunol. 2020, 11, 265. [CrossRef] 
52. Ahmadi, A.R.; Qi, L.; Iwasaki, K.; Wang, W.; Wesson, R.N.; Cameron, A.M.; Sun, Z. Orthotopic Rat Kidney Transplantantation: A Novel and Simplified Surgical Approach. JoVE 2019, e59403. [CrossRef]

53. Farrar, C.A.; Keogh, B.; McCormack, W.; O'Shaughnessy, A.; Parker, A.; Reilly, M.; Sacks, S.H. Inhibition of TLR2 promotes graft function in a murine model of renal Transplant ischemia-reperfusion injury. FASEB J. 2012, 26, 799-807. [CrossRef]

54. Gueler, F.; Shushakova, N.; Mengel, M.; Hueper, K.; Chen, R.; Liu, X.; Park, J.-K.; Haller, H.; Wensvoort, G.; Rong, S. A Novel Therapy to Attenuate Acute Kidney Injury and Ischemic Allograft Damage after Allogenic Kidney Transplantantation in Mice. PLoS ONE 2015, 10, e0115709. [CrossRef] [PubMed]

55. Sörensen, I.; Rong, S.; Susnik, N.; Gueler, F.; Shushakova, N.; Albrecht, M.; Dittrich, A.-M.; Von Vietinghoff, S.; Becker, J.U.; Melk, A.; et al. B B15-42 Attenuates the Effect of Ischemia-Reperfusion Injury in Renal Transplantantation. J. Am. Soc. Nephrol. 2011, 22, 1887-1896. [CrossRef] [PubMed]

56. Wang, J.-J.; Hockenheimer, S.; Bickerstaff, A.A.; Hadley, G.A. Murine Renal Transplantantation Procedure. J. Vis. Exp. 2009, 2009, e1150. [CrossRef]

57. Zhao, D.; Liao, T.; Li, S.; Zhang, Y.; Zheng, H.; Zhou, J.; Han, F.; Dong, Y.; Sun, Q. Mouse Model Established by Early Renal Transplantantation After Skin Allograft Sensitization Mimics Clinical Antibody-Mediated Rejection. Front. Immunol. 2018, 9, 1356. [CrossRef] [PubMed]

58. Plenter, R.; Jain, S.; Ruller, C.M.; Nydam, T.L.; Jani, A.H. Murine Kidney Transplantant Technique. J. Vis. Exp. 2015, 2015 , e52848. [CrossRef]

59. Giraud, S.; Favreau, F.; Chatauret, N.; Thuillier, R.; Maiga, S.; Hauet, T. Contribution of Large Pig for Renal Ischemia-Reperfusion and Transplantantation Studies: The Preclinical Model. J. Biomed. Biotechnol. 2011, 2011, 1-14. [CrossRef] [PubMed]

60. Cai, Q.; Fan, H.; Xiong, R.; Jiang, Y. A rat model of liver Transplantation with a steatotic donor liver after cardiac death. Int. J. Clin. Exp. Med. 2015, 8, 15724-15730.

61. Feng, Y.; Han, Z.; Feng, Z.; Wang, B.; Cheng, H.; Yang, L.; Li, Y.; Gu, B.; Li, X.; Li, Y.; et al. Approaching treatment for immunological rejection of living-donor liver Transplantation in rats. BMC Gastroenterol. 2020, 20, 1-11. [CrossRef]

62. Kashfi, A.; Mehrabi, A.; Pahlavan, P.S.; Schemmer, P.; Gutt, C.N.; Stahlheber, O.; Schmidt, J.; Büchler, M.W.; Kraus, T. A Review of Various Techniques of Orthotopic Liver Transplantantation in the Rat. Transplant. Proc. 2004, 78, 635. [CrossRef]

63. Martins, P.N.A. Assessment of graft function in rodent models of heart Transplantation. Microsurgery 2008, 28, 565-570. [CrossRef]

64. Wood, S.; Feng, J.; Chung, J.; Radojcic, V.; Sandy-Sloat, A.R.; Friedman, A.; Shelton, A.; Yan, M.; Siebel, C.W.; Bishop, D.K.; et al. Transient Blockade of Delta-like Notch Ligands Prevents Allograft Rejection Mediated by Cellular and Humoral Mechanisms in a Mouse Model of Heart Transplantantation. J. Immunol. 2015, 194, 2899-2908. [CrossRef]

65. Fu, X.; Segiser, A.; Carrel, T.P.; Stahel, H.T.T.; Most, H. Rat Heterotopic Heart Transplantantation Model to Investigate UnloadingInduced Myocardial Remodeling. Front. Cardiovasc. Med. 2016, 3, 34. [CrossRef]

66. Shan, J.; Huang, Y.; Feng, L.; Luo, L.; Li, C.; Ke, N.; Zhang, C.; Li, Y. A Modified Technique for Heterotopic Heart Transplantantation in Rats. J. Surg. Res. 2010, 164, 155-161. [CrossRef]

67. Laschinger, M.; Assfalg, V.; Matevossian, E.; Friess, H.; Huser, N. Potential of Heterotopic Cardiac Transplantantation in Mice as a Model for Elucidating Mechanisms of Graft Rejection. Card. Transpl. 2012, 125. [CrossRef]

68. Heron, I. A technique for accessory cervical heart Transplantation in rabbits and rats. Acta Pathol. Microbiol. Scand. Sect. A Pathol. 1971, 79, 366-372. [CrossRef] [PubMed]

69. Wu, W.; Qiu, Q.; Wang, H.; Whitman, S.A.; Fang, D.; Lian, F.; Zhang, N.D. Nrf2 Is Crucial to Graft Survival in a Rodent Model of Heart Transplantantation. Oxidative Med. Cell. Longev. 2013, 2013, 1-9. [CrossRef]

70. Wehner, J.R.; Morrell, C.N.; Rodriguez, E.R.; Fairchild, R.L.; Baldwin, W.M. Immunological Challenges of Cardiac Transplantantation: The need for Better Animal Models to Answer Current Clinical Questions. J. Clin. Immunol. 2009, 29, 722-729. [CrossRef] [PubMed]

71. Bribriesco, A.C.; Li, W.; Nava, R.G.; Spahn, J.H.; Kreisel, D. Experimental models of lung Transplantation. Front. Biosci. (Elite Ed.) 2013, 5, 266-272. [CrossRef]

72. Ruiz-Pérez, D.; Largo, C.; García-Río, F. Technical Aspects and Benefits of Experimental Mouse Lung Transplantantation. Arch. Bronconeumol. 2016, 52, 596-604. [CrossRef]

73. De Vleeschauwer, S.; Jungraithmayr, W.; Wauters, S.; Willems, S.; Rinaldi, M.; Vaneylen, A.; Verleden, S.; Widyastuti, A.; Bracke, K.; Brusselle, G.; et al. Chronic Rejection Pathology after Orthotopic Lung Transplantantation in Mice: The Development of a Murine BOS Model and Its Drawbacks. PLoS ONE 2012, 7, e29802. [CrossRef]

74. Johnson, A.C.; Huang, C.A.; Mathes, D.W. Tolerance Protocols in Large Animal VCA Models-Comprehensive Review. Curr. Transpl. Rep. 2020, 7, 270-278. [CrossRef]

75. Anderson, D.J.; Kirk, A.D. Primate Models in Organ Transplantantation. Cold Spring Harb. Perspect. Med. 2013,3 , a015503. [CrossRef] [PubMed]

76. Hammer, S.E.; Ho, C.-S.; Ando, A.; Rogel-Gaillard, C.; Charles, M.; Tector, M.; Tector, A.J.; Lunney, J.K. Importance of the Major Histocompatibility Complex (Swine Leukocyte Antigen) in Swine Health and Biomedical Research. Annu. Rev. Anim. Biosci. 2020, 8, 171-198. [CrossRef] [PubMed]

77. Dehoux, J.-P.; Gianello, P. The importance of large animal models in Transplantation. Front. Biosci. 2007, 12, 4864-4880. [CrossRef] [PubMed] 
78. Faria, J.; Ahmed, S.; Gerritsen, K.G.F.; Mihaila, S.M.; Masereeuw, R. Kidney-based in vitro models for drug-induced toxicity testing. Arch. Toxicol. 2019, 93, 3397-3418. [CrossRef] [PubMed]

79. Fransen, M.F.; Addario, G.; Bouten, C.V.; Halary, F.; Moroni, L.; Mota, C. Bioprinting of kidney in vitro models: Cells, biomaterials, and manufacturing techniques. Essays Biochem. 2021, 65, 587-602. [CrossRef]

80. Kinoshita, Y.; Iwami, D.; Fujimura, T.; Kume, H.; Yokoo, T.; Kobayashi, E. Techniques of orthotopic renal Transplantation in pigs. One donor to two recipients via inverted grafting. Acta Cir. Bras. 2021, 36, e360208. [CrossRef]

81. Packialakshmi, B.; Stewart, I.J.; Burmeister, D.M.; Chung, K.K.; Zhou, X. Large animal models for translational research in acute kidney injury. Ren. Fail. 2020, 42, 1042-1058. [CrossRef]

82. Zonta, S.; Lovisetto, F.; Lorenzo, C.; Abbiati, F.; Alessiani, M.; Dionigi, P.; Zonta, A. Uretero-neocystostomy in a swine model of kidney Transplantation: A new technique. J. Surg. Res. 2005, 124, 250-255. [CrossRef] [PubMed]

83. Golriz, M.; Fonouni, H.; Nickkholgh, A.; Hafezi, M.; Garoussi, C.; Mehrabi, A. Pig Kidney Transplantantation: An Up-To-Date Guideline. Eur. Surg. Res. 2012, 49, 121-129. [CrossRef] [PubMed]

84. Inomata, K.; Tajima, K.; Yagi, H.; Higashi, H.; Shimoda, H.; Matsubara, K.; Hibi, T.; Abe, Y.; Tsujikawa, H.; Kitago, M.; et al. A Pre-Clinical Large Animal Model of Sustained Liver Injury and Regeneration Stimulus. Sci. Rep. 2018, 8, 1-12. [CrossRef] [PubMed]

85. Leal, A.J.G.; Tannuri, A.C.A.; Belon, A.R.; Guimarães, R.R.N.; Coelho, M.C.M.; Gonçalves, J.D.O.; Serafini, S.; De Melo, E.S.; Tannuri, U. Effects of ischemic preconditioning in a pig model of large-for-size liver Transplantation. Clinics 2015, 70, 126-135. [CrossRef]

86. Siefert, J.; Hillebrandt, K.H.; Moosburner, S.; Podrabsky, P.; Geisel, D.; Denecke, T.; Unger, J.K.; Sawitzki, B.; Gül-Klein, S.; Lippert, S.; et al. Hepatocyte Transplantantation to the Liver via the Splenic Artery in a Juvenile Large Animal Model. Cell Transplantant. 2019, 28, 14S-24S. [CrossRef]

87. Forbes, S.J.; Gupta, S.; Dhawan, A. Cell therapy for liver disease: From liver Transplantation to cell factory. J. Hepatol. 2015, 62, S157-S169. [CrossRef]

88. Spannbauer, A.; Traxler-Weidenauer, D.; Zlabinger, K.; Gugerell, A.; Winkler, J.; Mester-Tonczar, J.; Lukovic, D.; Müller, C.; Riesenhuber, M.; Pavo, N.; et al. Large Animal Models of Heart Failure With Reduced Ejection Fraction (HFrEF). Front. Cardiovasc. Med. 2019, 6, 117. [CrossRef]

89. Ribeiro, R.V.P.; Alvarez, J.S.; Yu1, F.; Adamson, M.B.; Fukunaga, N.; Serrick, C.; Bissoondath, V.; Meineri, M.; Badiwala, M.V.; Rao, V. A Pre-Clinical Porcine Model of Orthotopic Heart Transplantantation. JoVE 2019, e59197. [CrossRef]

90. Bianco, R.W.; Gallegos, R.P.; Rivard, A.L.; Voight, J.; Dalmasso, A.P. Animal Models for Cardiac Research. In Handbook of Cardiac Anatomy, Physiology, and Devices; Springer: Berlin/Heidelberg, Germany, 2009; pp. 393-410.

91. Nelson, K.; Bobba, C.; Ghadiali, S.; Jr, D.H.; Black, S.M.; A Whitson, B. Animal models of ex vivo lung perfusion as a platform for Transplantation research. World J. Exp. Med. 2014, 4, 7-15. [CrossRef]

92. Mariscal, A.; Caldarone, L.; Tikkanen, J.; Nakajima, D.; Chen, M.; Yeung, J.; Cypel, M.; Liu, M.; Keshavjee, S. Pig lung Transplant survival model. Nat. Protoc. 2018, 13, 1814-1828. [CrossRef]

93. Woodall, J.D.; Schultz, B.D.; Sosin, M.; Barth, R.N. Large Animal Models for Vascularized Composite AlloTransplantation. Curr. Transpl. Rep. 2014, 1, 190-196. [CrossRef]

94. Figueiredo, C.; Oliveira, M.C.; Chen-Wacker, C.; Jansson, K.; Hoeffler, K.; Yuzefovych, Y.; Pogozhykh, O.; Jin, Z.; Kuehnel, M.; Jonigk, D.; et al. Immunoengineering of the Vascular Endothelium to Silence MHC Expression During Normothermic Ex Vivo Lung Perfusion. Hum. Gene Ther. 2019, 30, 485-496. [CrossRef]

95. Hackam, D.G.; Redelmeier, D.A. Translation of Research Evidence from Animals to Humans. JAMA 2006, $296,1727-1732$. [CrossRef]

96. Anderson, D.J.; Martin, B.M.; Kirk, A.D.; Sachs, D.H. Large Animal Models of Transplantantation. Textb. Organ Transpl. 2014, 185-207. [CrossRef]

97. Brandacher, G.; Grahammer, J.; Sucher, R.; Lee, W.-P.A. Animal models for basic and translational research in reconstructive Transplantation. Birth Defects Res. Part C Embryo Today Rev. 2012, 96, 39-50. [CrossRef]

98. Cendales, L. Animal Models in Immunology and Transplantant Medicine. ILAR J. 2011, 52, 498-501. [CrossRef]

99. Robinson, N.B.; Krieger, K.; Khan, F.M.; Huffman, W.; Chang, M.; Naik, A.; Yongle, R.; Hameed, I.; Krieger, K.; Girardi, L.N.; et al. The current state of animal models in research: A review. Int. J. Surg. 2019, 72, 9-13. [CrossRef] [PubMed] 